\title{
The Effect of Poison Pill Adoptions and Court Rulings on Firm Entrenchment
}

\author{
Randall A. Heron \\ Kelley School of Business \\ Indiana University \\ 801 W. Michigan Street \\ Indianapolis, IN 46202 \\ Tel: 317-274-4984 \\ Email: rheron@iupui.edu
}

Journal of Corporate Finance, forthcoming

\begin{abstract}
We challenge a common presumption that poison pills and two Delaware case rulings in 1995 validating such pills materially entrench firms. Based on unsolicited takeover attempts from 1985 to 2009, we find that poison pills enhance takeover premiums, but do not reduce completion rates. Furthermore, the 1995 Delaware rulings affected neither the use of poison pills among the targets, the effectiveness of the pills that were used, the completion rate of the takeover attempts, nor the takeover premiums.
\end{abstract}

This is the author's manuscript of the article published in final edited form as:

Heron, R. A., \& Lie, E. (2015). The effect of poison pill adoptions and court rulings on firm entrenchment. Journal of Corporate Finance, 35, 286-296. http://doi.org/10.1016/j.jcorpfin.2015.09.008 


\section{Introduction}

Two landmark Delaware Supreme Court rulings in 1985 have played significant roles in corporate control contests during the ensuing decades. In the first case, Unocal Corp. v. Mesa Petroleum Co., the Delaware Supreme Court established guidelines for what constitutes a legitimate response to a perceived takeover threat by the target's Board of Directors. To justify its defensive measures under the Unocal standard, the target's Board must show that (1) it had a reasonable basis to believe that a legitimate threat to the corporation existed, and (2) its response is reasonable in relation to the threat posed. Thus, the Unocal ruling enhanced the level of scrutiny placed on defensive measures beyond the protections afforded by the business judgment rule to also include the potential for a judicial review. In the second case, Moran v. Household International Inc., the Delaware Supreme court validated the use of a poison pill plan as a legitimate response to a takeover bid under the Unocal standard. This triggered a surge in adoptions of poison pill plans and permanently altered the takeover landscape. For example, Ryngaert (1989) reports an 850\% increase in poison pill plans between the court ruling and the end of 1986.

Since the Moran v. Household ruling, courts applying Delaware law have validated numerous other poison pills under the Unocal standard. The two cases that have attracted the most attention among finance researchers were both concluded in 1995, namely Unitrin, Inc. $v$. American General Corp. and Moore Corp. v. Wallace Computer Services, Inc. (hereafter, the “1995 Delaware rulings”). Indeed, in the search for a solution to the pervasive endogeneity problem in research on governance, a growing body of literature singles out the 1995 Delaware rulings as an exogenous shock that unexpectedly and effectively insulated managers of Delaware-incorporated firms from the market for corporate control. As such, the rulings have 
been used as an instrument to study the effect of managerial entrenchment on corporate behavior. For example, empirical studies report that, after 1995, Delaware firms exhibit decreases in employee ownership within defined contribution plans (Rauh, 2006), risk (Low, 2009), and credit lines (Yun, 2009), and increases in cash holdings (Yun, 2009) and executive compensation (Bereskin and Cicero, 2013), all of which have been attributed to enhanced managerial entrenchment.

In this study, we dispute the use of the 1995 Delaware rulings as an exogenous entrenchment shock for several reasons. We outline the reasons here and discuss them in detail in the next section. First, the Moran $v$. Household and other rulings had already paved the way for the use of poison pills. Second, any effect of the 1995 Delaware rulings likely extend beyond the state of Delaware, rendering difference-in-difference tests based on Delaware and nonDelaware firms invalid. In this regard, it is also relevant that one of the 1995 Delaware rulings was actually a Federal court ruling on Delaware law, and it would not be binding for later Delaware court cases. Third, there is no extant evidence that Delaware firms became more entrenched after 1995. Fourth, there is no convincing evidence that the poison pills that the 1995 rulings validated are associated with entrenchment.

Our study directly tests whether the 1995 Delaware rulings had any significant and lasting effect. To do so, we examine hostile takeover attempts from 1985 to 2009, with a particular emphasis on the use of poison pills among the targets. Comment and Schwert's (1995) sample ends in 1991, so the lack of a deterrent effect from poison pills that they demonstrate might not extend to the post-1995 environment. Heron and Lie’s (2006) sample covers the period from 1985 through 1998, thus primarily before the 1995 rulings, and they do not examine whether the results vary across time. We are interested in examining whether targets of hostile takeovers are 
more likely to adopt poison pills after the 1995 Delaware rulings, whether the rulings generally altered the outcomes of the hostile takeover attempts, and whether poison pills adopted after the rulings were more effective in thwarting takeovers or extracting higher premiums from the bidders.

As noted earlier, it is unclear whether any effect from the 1995 Delaware rulings pertains to only Delaware firms or all US firms. But what is clear is that studies using the rulings as an exogenous shock presume that there is an effect and that the effect is significantly stronger for Delaware firms. Thus, we design our tests primarily to gauge whether the rulings affected Delaware firms. However, our research design also allows us to examine whether the rulings had a broader effect, with the important caveat that tests for a broader effect from the rulings might be influenced by unrelated time-variant effects.

In our initial test, we document that, relative to non-Delaware firms, Delaware firms were no less likely to be targeted in hostile takeover attempts after than before 1995 . Thus, there is no evidence to suggest that the 1995 Delaware rulings contributed to keeping hostile suitors at bay. Next, we examine the determinants of poison pill adoptions among target firms. Consistent with Heron and Lie (2006), the most important determinant is insider ownership. In particular, firms that have low insider ownership, and, thus, presumably are more vulnerable to hostile takeover attempts, are more likely to adopt poison pills. More importantly for the purposes of our study, we find no evidence that target firms are more likely to employ poison pills after the 1995 Delaware rulings, regardless of whether the firms are incorporated in Delaware. Thus, the rulings did not spur an increase in the use of poison pills to cope with potential hostile bidders.

Even if the 1995 Delaware rulings had no effect on the frequency with which targets use 
pills, the rulings could alter the effectiveness of those pills or have a broader effect irrespective of whether pills are used. Thus, we carefully examine the outcome of the takeover attempts. We find that a takeover attempt is more likely to succeed if the bidder increases the bid beyond the initial bid, such that the final bid is comparatively high. We also find that a bidder is less likely to succeed when there are competing bidders, but that the probability that the target will be acquired is higher when there are multiple bidders. However, regardless of whether the takeover attempts occur after 1995, the target is incorporated in Delaware, or both, the outcome is similar, and poison pills do not significantly affect the probability of success for a bidder or the probability that the target is acquired by any bidder.

We further find that multiple bidders are associated with greater bid increases during the contest, which in turn result in higher final premiums. Also, consistent with Heron and Lie (2006), poison pills induce greater final takeover premiums, mostly as a result of bid increases after the initial bid. But the 1995 Delaware rulings have no general effect on the takeover premiums (although there is a slight decline in premiums after 1995 that is hard to attribute to the rulings), nor do they alter the effect that poison pills have on the takeover premiums.

Overall, we find no evidence that the 1995 Delaware rulings had any effect on hostile takeover activity or outcomes, either via the poison pills that the rulings address, or more generally. On this basis, we argue that the rulings had a trivial effect on firm entrenchment and cannot be used as an exogenous entrenchment shock to infer the consequences of entrenchment on corporate behavior. In this regard, our study joins an emerging literature (e.g., Atanasov and Black (2015a) and Atanasov and Black (2015b)) that questions some of the causal inferences from the use of exogenous shocks to examine corporate governance issues. Nonetheless, we remain guarded in interpreting the published evidence on the effect of the 1995 Delaware rulings 
other than to say that there is no evidence that any observed changes in behavior among Delaware firms around 1995 are attributable to increased entrenchment. ${ }^{1}$

\section{The 1995 Delaware rulings as an exogenous entrenchment shock}

In 1985, a few years after the introduction of poison pills, the Moran v. Household ruling validated the use of poison pills to defend against coercive bids. But the Delaware courts (and other courts) have subsequently made numerous important rulings on poison pills or closely related matters. We discuss some of these rulings here. The cases leading up to the 1995 Delaware rulings are particularly relevant for the argument that the 1995 rulings represent an exogenous entrenchment shock.

In 1988 in City Capital Associates Ltd. v. Interco Inc., the Delaware Chancery Court established that “[e]ven where an offer is noncoercive, it may represent a 'threat' to shareholder interests." Yet, "in the setting of a noncoercive offer, absent unusual facts, there may come a time when a board's fiduciary duty will require it to redeem the rights and to permit the shareholders to choose." That is, once the board "has taken such time as it required in good faith to arrange an alternative value-maximizing transaction, then, in most instances, the legitimate role of the poison pill in the context of a noncoercive offer will have been fully satisfied.” The court ruled that the tender offer posed a mild threat and did not justify the pill, despite the board's belief that the offer was inadequate.

\footnotetext{
1 While we are interested primarily in whether or not the collective evidence supports the interpretation that the 1995 Delaware Court rulings were truly watershed events that effectively insulated managers from unwanted takeovers and we are not proposing alternative explanations at this point, it is worth noting that overall economic conditions improved substantially from 1994 to 1995. For instance, throughout 1994 the economy was beginning to improve rapidly, prompting the Federal Reserve to double the Federal Funds Rate from 3\% at the start of 1994 to 6\% by early 1995 . The return on the S\&P 500 (including dividends) rose from $1.32 \%$ in 1994 to $37.58 \%$ in 1995 and continued to exceed $20 \%$ every year through 1999 . Variations in economic factors across states and time inevitably affect corporate decisions and behavior in systematic manners.
} 
A year thereafter in Paramount Communications, Inc. v. Time, Inc., the Delaware Supreme Court criticized the lower court's Interco ruling. The Supreme Court explicitly rejected an application of the Unocal standard that "would involve the court in substituting its judgment as to what is a 'better' deal for that of a corporation's board of directors." The court further recognized substantive coercion - "the risk that shareholders will mistakenly accept an underpriced offer because they disbelieve management's representations of intrinsic value” - as a threat. Thus, although the court's ruling did not directly address poison pills, it had significant implications for poison pill jurisprudence. That is, the ruling suggested that boards can adopt poison pills to reject indefinitely any bid, as long as the board believes that the firm's strategy eventually will produce greater value than the bid.

Then we get to the two cases in 1995. In Unitrin, Inc. v. American General Corp., American General Corp. tendered an offer for a controlling interest in Unitrin Inc. The Unitrin Board of Directors viewed American General's takeover offer to be inadequate, and, consequently, adopted a poison pill and offered to conduct a stock repurchase to increase the board of directors' ownership from $23 \%$ to $28 \%$. The trial court viewed the takeover offer to be a threat of substantive coercion and ruled that the poison pill was a reasonable response. But it also ruled that the repurchase was disproportionate because the pill was already in place. The Delaware Supreme Court overturned the trial court's ruling on the repurchase, holding that the trial court "erred by substituting its judgment, that the Repurchase Program was unnecessary, for that of the board."

In Moore Corp. Ltd. v. Wallace Computer Services, Inc., Moore launched a tender offer for Wallace Computer Services at a 45\% premium above the market price. Although more than $70 \%$ of Wallace shares were tendered, Wallace's poison pill prevented the completion of the 
offer. Moore was successful in replacing one-third of Wallace’s staggered board via a proxy fight, but it would take at least another year and successful proxy contest to gain the board majority. Despite the apparent support from Wallace's shareholders, Moore's hostile takeover attempt was unsuccessful. ${ }^{2}$ Because Wallace was a Canadian corporation while Moore was incorporated in Delaware, the Federal District Court was deemed to be the appropriate jurisdiction based on diversity of citizenship. ${ }^{3}$ The Federal District Court, interpreting and applying Delaware law, found that "the Moore tender offer pose[d] a threat to Wallace that shareholders, because they are uninformed, will cash out before realizing the fruits of the substantial technological innovations achieved by Wallace," and that the board response was reasonable, even in conjunction with the staggered board, because the pill would not impair the likelihood of success in a proxy fight.

There have also been several recent validations of poison pills. In 2010 in Selectica, Inc. v. Versata Enterprises, Inc., the Delaware court allowed the use of poison pills to protect valuable corporate assets, in this case net operating losses (NOLs). In the same year in Yucaipa American Alliance Fund II, L.P. v. Riggio, the court permitted a pill that grandfathered in a higher ownership stake than the pill threshold. In 2011 in Air Products and Chemicals, Inc. v. Airgas Inc., the Delaware court validated a poison pill plan on the basis of the threat posed by an “inadequate offer price,” even after Air Products (the suitor) waged a successful proxy contest to gain control of one third of the target's board of directors. ${ }^{4}$ While waiting for this ruling, the

\footnotetext{
2 Moore Corporation successfully acquired Wallace Computer in a friendly acquisition in 2003.

3 Diversity of citizenship is codified in 28 U.S. Code $\S 1332$.

4 The Air Products $v$. Airgas case also illustrates the effect of staggered boards in takeover contests involving poison pills. In particular, the staggered board limited Air Products to $1 / 3$ of the board seats via the proxy fight, so it would effectively take at least two separate board elections to gain board control. But once they gained access to additional information and performed their due diligence in their role as Airgas Board members, all three directors that Air Products placed on the board concluded that the Air Products offer was inadequate and that Airgas should maintain
} 
Wall Street Journal wrote on January 18, 2011, that “Corporate attorneys are calling it one of the most significant legal decisions in a generation, one that could affect the balance of power between boards and shareholders.” Finally, in 2014 in Third Point LLC v. Ruprecht, et al., the Delaware court validated a poison pill that discriminated against activist investors. ${ }^{5}$

We dispute the use of the 1995 Delaware rulings as an exogenous entrenchment shock for four major reasons. First, the Moran v. Household ruling had already paved the way for the use of poison pills, leaving subsequent rulings with a smaller effect on managerial entrenchment. And, there are many other Delaware rulings that arguably are at least as significant as the 1995 Delaware rulings. Our reading of recent court rulings and conversations with corporate lawyers support this view. For example, the conclusion of Air Products and Chemicals, Inc. v. Airgas Inc. ruling states that "The mechanisms in place to get around the poison pill—even a poison pill in combination with a staggered board, which no doubt makes the process prohibitively more difficult-have been in place since 1985, when the Delaware Supreme Court first decided to uphold the pill as a legal defense to an unwanted bid. That is the current state of Delaware law until the Supreme Court changes it." 6 It is also of interest here that the 153-page ruling did not cite the Moore Corp. Ltd. v. Wallace Computer Services, Inc. Federal Court ruling even once, even though both cases involved a staggered board. While the Federal Court in Moore Corp. Ltd. v. Wallace Computer Services, Inc. was required to interpret and apply Delaware law, its ruling does not bind Delaware courts in applying Delaware law.

its poison pill plan. Thus, Air Products lost all of the ground gained from the seemingly successful election of their chosen directors.

5 The poison pill plan of auction house Sotheby's set the ownership limits of activist investors and passive investors to $10 \%$ and $20 \%$, respectively. Hedge fund mogul Dan Loeb and his firm Third Point challenged this plan on the grounds that it unfairly impeded the ability to wage a campaign against Sotheby's. But in a ruling from May 2014, a Delaware Court of Chancery judge blocked efforts to remove the plan.

6 Air Products and Chemicals Inc. v. Airgas, Inc. (Del. Ch., CA No. 5249-CC), page 153. 
Second, studies that use the rulings as an exogenous shock rely on the presumption that the entrenchment effect is largely limited to Delaware firms, and, thus, use difference-indifference tests to infer causation. However, because of the sophistication and influence of the Delaware courts, their decisions often form persuasive legal precedents for other states as well. Indeed, Cremers and Ferrell (2014) point out that "Delaware corporate law decisions have a leading role in shaping corporate law in all other states, affecting expectations about legal decisions concerning firms incorporated in other states” (pp. 1169-1170). If Delaware court rulings have a nationwide effect, their effect is difficult to disentangle from other time-variant effects, and difference-in-difference tests based on Delaware and non-Delaware firms over time are inappropriate.

Third, we are unaware of large-scale empirical evidence that Delaware-incorporated firms (or firms in general) became significantly more entrenched after 1995. Instead, Kaplan and Minton (2012) find that CEO turnover has increased in recent years, which is inconsistent with the notion of greater managerial entrenchment. The motivation for using the 1995 rulings appears to trace back to Subramanian (2004). Subramanian mentions the 1995 Delaware rulings among several possible explanations for the disappearance of the so-called "Delaware effect" i.e., the superior value of firms in Delaware - as reported by Daines (2001). But Subramanian also shows that the Delaware effect only existed for small firms, representing a measly two percent of total market capitalization. And even Subramanian offers no evidence that the 1995 Delaware rulings affected managerial entrenchment.

Fourth, extant literature offers no convincing evidence that the poison pills that the 1995 Delaware rulings validated are associated with managerial entrenchment. Early studies of poison pill plans (Malatesta and Walkling, 1988; Ryngaert, 1988) report negative abnormal returns upon 
pill adoptions, which are often interpreted as evidence that poison pill plans entrench management. However, Comment and Schwert (1995) challenge the interpretation of abnormal returns upon poison pill adoptions, arguing that the market reaction might contain information about imminent or ongoing takeover attempts. They further speculate that "the market misestimated the eventual effect of pills and laws, over-estimating the costs of deterrence and underestimating the benefits of added bargaining power” (p. 38). To provide more direct evidence on the effect of poison pills, Comment and Schwert relate the use of poison pills to takeover rates from 1975 to 1991 . Their tests show that poison pills did not materially alter takeover likelihood, but did contribute to higher gains in successful takeovers. More recently, Heron and Lie (2006) examine the effects of poison pill plans in unsolicited takeover attempts and find that poison pills contribute to higher premiums offered to target shareholders, yet do not materially alter the likelihood of acquisition success. Ryngaert and Scholten (2010) examine the entrenchment issue by contrasting shareholder wealth outcomes and managerial turnover following defeated takeover bids before and after the 1989 Paramount Communications Inc. vs. Time Inc. decision, a ruling that is frequently interpreted as validating a "just say no" defense against unwanted takeovers. If the court ruling contributed to increased managerial entrenchment, one would expect to find worse shareholder wealth outcomes and reduced managerial turnover following defeated takeover bids after the decision vs beforehand. However, this is not borne out in the data. Instead, Ryngaert and Scholten found average contest related stock returns and post-offer discounts to be nearly the same for the 1980s and 1990s. ${ }^{7}$ With regard to managerial turnover, they find that over the two years subsequent to a defeated takeover attempt, the CEOs of targeted firms were more likely to lose their jobs and the targeted

\footnotetext{
${ }^{7}$ In fact, the period that pre-dates the use of poison pills (1980-1984) exhibits the worst shareholder outcomes.
} 
firms were just as likely to be subsequently acquired in post Paramount Communications Inc. vs. Time Inc. era. Collectively, their results run counter to the notion that the court ruling bolstered managerial entrenchment.

Lastly, Cain et al. (2014) report that a firm's probability of being acquired through hostile means increased following poison pill validation by law and state statues (although their results primarily capture the Moran v. Household decision and they did not consider subsequent Delaware rulings). In sum, there is no direct evidence to suggest that on the whole, poison pills entrench managers. Thus, it is questionable whether any rulings validating pills, including the 1995 Delaware rulings, served to entrench managers.

\section{Sample}

We construct our initial sample of unsolicited acquisition attempts announced between 1985 and 2009 from the Securities Data Company (SDC) Mergers and Acquisitions database. We consider takeover attempts that the SDC database classifies to be either hostile or unsolicited. We require the sample firms to be covered on CRSP and Compustat so that we can utilize financial data and stock trading data in our analysis, and that they have at least one year of stock returns available on CRSP over the 250 trading days (approximately one year) prior to the announcement of the takeover offer. Takeover offers that were made when the firms were in the midst of a bankruptcy reorganization process are excluded. We collected information on CEO compensation, board composition and structure, and ownership by officers and directors from proxy statements immediately preceding the takeover attempts. The adoption dates for poison pills come from searching various editions of the Clark Boardman publication entitled 
“Corporate Anti-Takeover Defenses: The Poison Pill Device”, Dow Jones News Retrieval / Factiva, and FactSet’s SharkRepellent database.

To ensure that our conclusions are not attributable to extremely small firms and/or extreme returns for low-priced stocks, we exclude firms with either assets or equity market values less than $\$ 10$ million and stock prices less than $\$ 3$ as of 20 days prior to the announcement of the takeover offer. Because takeover premiums play a significant role in our analysis and conclusions, we exclude four firms from the final analysis because the windows we use to capture takeover premiums included either the 1987 or 2008 stock market crashes. Prior to controlling for multiple unsolicited bids, the sample consists of 694 hostile or unsolicited takeover offers.

Because of our interest in identifying the extent to which poison pills plans contribute to eventual takeover outcomes and shareholder premiums, it is important to properly control for multiple bidder contests. To do so, we first measure premiums offered relative to target firm share prices prior to initial bids in multiple bidder contests so that we can isolate how much the bidding contests contribute to increased premiums. We further use an indicator variable to identify multiple bidder contests. In many cases, the competing bidder will be a friendly offer that would not otherwise enter our sample, and, if so, our sample design captures this properly without double counting through the multiple bidder dummy indicator. However, there are several cases where the offers from competing parties were also classified as unsolicited offers, and the outcomes are therefore picked up multiple times in our sample construction, creating a potential double-counting situation. To prevent this type of double-counting from affecting our summary statistics and multivariate models, we allow multiple unsolicited bids in a bidding contest to enter the sample only once during our statistical analyses by including only one of the observations (i.e., the record for the first unsolicited offer) used in combination with a multiple 
bidder indicator variable. Thirty-two instances of unsolicited bids in multiple bidder contests were removed to prevent double-counting, so the final reported sample consists of 662 takeover contests involving unsolicited bids.

Table 1 provides descriptive statistics for the sample. The mean and median equity market values for the targeted firms (as of 20 days prior to the initial announcement) are \$1.112 billion and \$191 million, respectively. The mean and median debt ratios are both 56\%, which are statistically indistinguishable from corresponding figures for industry peers (as determined by the median figure for firms in the same Fama-French 48 industry classifications). The mean cash and short term investment ratios of $11.3 \%$ exceed the mean of $8.9 \%$ for industry peers (statistically significant at the 0.01 level), while the median ratio of $5.8 \%$ for the sample firms is similar to that of $5.7 \%$ for industry peers. The mean (median) market-to-book ratios of 1.36 (1.15) are significantly lower than those for industry peers of $1.42(1.31)$ at the $0.05(0.01)$ statistical significance level. The mean and median industry-adjusted operating income before depreciation are $2.6 \%$ and $1.6 \%$ and statistically different from zero at the 0.01 significance level. The stock returns for target firms before the takeover attempts tend to be below those for the overall stock market (as proxied by the CRSP value-weighted return) and the target firms' industries (as proxied by value-weighting the returns in the same Fama-French 48 industry classification). For instance, the mean (median) stock return for the sample firms during the year prior to the takeover attempt is $5.2 \%$ (1.9\%), compared to that for the overall market of $12.5 \%$ (16.1\%) and the industry of $24.3 \%$ (22.2\%) over the same interval. This is consistent with the notion that recent poor stock price performance increases the likelihood that a firm will receive an unsolicited takeover offer. 
The mean initial premium offered is $36.4 \%$ and the median is $33.3 \%$. The majority of offers are increased relative to the initial offer, with a mean increase of $14.7 \%$ and a median increase of $8.1 \%$. Roughly $56 \%$ of the targets (369 out of 662) either had a poison pill plan already in place (43\%) or adopted a morning-after pill (13\%) in response to the unsolicited offers. Over half of the target firms have staggered terms for the board of directors (51\%) and over threefifths (62\%) have CEOs that also serve as the chairperson of the board. While only $21 \%$ of the unsolicited offers are successful, this figure can be misleading in characterizing the resolution of takeover attempts, because a significant number of contests have multiple bidders (266 of 662, or $40 \%$ of the sample), which often culminate with an acquisition, but in many cases by a competing bidder. For example, 187 of the targeted firms (28\%) were acquired by competing bidders. Collectively, of the 662 takeover attempts, 325, or 49\%, end up with the targeted firm either being acquired by the bidder or by a competing bidder. Thus, failing to properly consider the resolution of contests with multiple bidders could give rise to a significant bias toward the inference that takeover defenses serve as entrenchment devices and against the inference that takeover defenses contribute toward higher takeover premiums.

\section{Univariate comparisons}

Table 2 provides univariate comparisons for subsamples based on either the outcome (i.e., whether the firm was ultimately acquired by either the bidder or by a competing bidder) or whether the targeted firm had a poison pill (either already in place or adopted in response to the takeover attempts as a morning-after pill). There are no significant differences between firms that were acquired vs. others in terms of size, debt ratios, market-to-book ratios, use of poison pills, staggered boards, and duality of CEO/Chairman of the Board. Acquired firms tend to have 
slightly lower insider ownership, reflecting that higher levels of insider ownership helps to insulate firms from hostile takeovers. As expected, the premiums offered are higher for successful contests than for unsuccessful contests; the typical initial premium offered is roughly 4-5\% higher for successful contests, and this gap increases to more than $20 \%$ when considering subsequent premium increases.

Firms that use poison pills have, on average, a market capitalization of $\$ 1.4$ billion, about double that of other firms, and insider ownership of $9.0 \%$, about half that of other firms. Moreover, firms that use poison pill plans have, on average, greater outside board representation (62\% vs. 55\%) and higher industry-adjusted levels of operating performance (3.7\% vs. 1.3\%). Perhaps most interestingly, while the mean initial premium does not differ statistically for firms with and without pills (38\% vs. 35\%), the mean premium increase and the mean total premium for firms that use poison pills of $18 \%$ and 56\%, respectively, are significantly higher than comparable means of $11 \%$ and $45 \%$, respectively, for firms that do not use poison pills. This shows that, at least on a univariate basis, poison pills are associated with higher total premiums resulting from premium increases during the contest.

Table 3 provides a further decomposition of the sample based on whether the takeover attempt was announced after the 1995 Delaware rulings (i.e., 1985-1995 vs. 1996-2009) and whether the target is incorporated in the state of Delaware. The proportion of targeted firms incorporated in Delaware increased from 57.5\% (226 of 393) through 1995 to 62\% (167 of 269) in the post 1995 period. Furthermore, the proportion of Delaware targets that were acquired declined from $49.1 \%$ to $45.5 \%$ from before to after 1995 (a statistically insignificant decline), whereas the proportion for non-Delaware targets declined more markedly from $56.3 \%$ to $43.1 \%$ 
(a statistically significant decline at the 0.01 level). On these bases, there is no evidence to suggest that Delaware firms became more entrenched after 1995 relative to other firms.

For Delaware targets, the mean (median) premium declined from 53.7\% (45.5\%) before 1995 to $46.0 \%$ (40.8\%) after 1995, and the p-values for both the mean and the median difference are less than 0.05 . The decline in premium over time is slightly more pronounced for nonDelaware targets; the mean (median) premium is 56.1\% (50.8\%) before 1995 and $45.6 \%$ (43.7\%) after 1995, and the p-values for both the mean and the median difference are less than 0.01 . The proportion of contests with multiple bidders remained constant at about $40 \%$ (there was a slight increase among Delaware targets and a slight decrease among non-Delaware targets, but none of the changes are statistically significant). Delaware targets are more likely than non-Delaware firms to use poison pills (about 60\% vs. 50\%), and both types of targets exhibit a statistically insignificant increase in the use of poison pills from before to after 1995.

\section{Multivariate tests}

\subsection{The use of poison pills}

In our first multivariate test, we examine the probability that targets use a poison pill plan. Table 4 presents a regression of the probability that a poison pill plan is adopted against variables designed to capture the effects of the 1995 Delaware rulings and various control variables. The two variables for the 1995 Delaware rulings are (1) a post 1995 dummy that captures the effect across all firms, and (2) an interaction between the post 1995 dummy and a Delaware incorporation dummy that captures the effect that pertains only to targets incorporated in Delaware. As noted earlier, it is unclear whether the 1995 Delaware rulings affect only Delaware firms, and, thus, which of these variables capture the bulk of the effect of the rulings. 
The coefficient on insider ownership negative, and it is the only coefficient that is statistically significant at the 0.01 level. The negative coefficient is consistent with Malatesta and Walkling (1988) and Heron and Lie (2006), and suggests that firms with sufficiently high insider ownership can effectively block unwanted takeovers, whereas firms with low levels of insider ownership use poison pills to boost their otherwise low bargaining power. The coefficient on the staggered board variable is significantly positive at the 0.10 level, perhaps reflecting the complementarity of poison pills and classified boards as delay tactics in unsolicited takeover attempts.

Neither the coefficient on the post 1995 dummy nor the coefficient on the interaction variable between the Delaware and post 1995 variables differs statistically from zero. Thus, even though the 1995 Delaware rulings specifically validated the use of poison pills, they have no discernible effect on targets' use of poison pills, irrespective of whether the targets were incorporated in Delaware.

\subsection{Takeover outcomes}

We next turn to our multivariate analysis of takeover outcomes. Table 5 presents logistic regressions of whether the takeover succeeds (model a) and whether the firm is acquired by any of the bidders involved (model b). In model a, the coefficient on the multiple bidder dummy is negative and statistically significant, suggesting that an individual unsolicited takeover offer is less likely to be successful in the presence of competing bidders. In model b, the coefficient on the multiple bidder dummy turns positive and statistically significant, suggesting that it is more likely that the target will be acquired when there is proven interest from multiple parties. Both of these coefficients have the expected signs and highlight the importance of controlling for the competition between interested parties when examining the outcome of a takeover contest. 
As expected, a higher premium increases both the chance that a takeover attempt succeeds and that the target is acquired by one of the bidders. The effect is evident for both parts of the total premiums, i.e., the initial premium offered and any premium increases. But the magnitudes of the coefficients suggest that premium increases have a greater impact on the outcome than on initial premiums offered. One implication of these results is that bidders trying to close the deal should save part of the initial premium for later premium increases during the bargaining process.

As earlier, we capture the 1995 Delaware rulings effects via two variables, i.e., a post 1995 dummy and an interaction between the post 1995 dummy and the Delaware dummy. If the 1995 Delaware rulings have a general entrenchment effect, our variables should have negative coefficients. We also examine whether the 1995 Delaware rulings affect the outcome indirectly by strengthening the effect of poison pills. To do so, we interact the same two variables with our poison pill variable, and conjecture that the associated coefficients are negative.

Our results show that neither the coefficient on the post 1995 dummy nor the coefficient on the post 1995 dummy interacted with the Delaware dummy is statistically significant. Thus, there is no evidence that the 1995 Delaware rulings entrench firms that are targets of hostile takeovers. The coefficient on the poison pill is not statistically significant either, suggesting that poison pills have no detectable effect on takeover likelihood. Finally, the coefficients on the interaction variables - the poison pill dummy interacted with the post 1995 dummy and the poison pill dummy interacted with both the post 1995 dummy and the Delaware dummy - are not statistically significant. Thus, there is no evidence that the 1995 Delaware rulings strengthened the effect of poison pills. In fact, there is no evidence in table 5 that poison pills had any effect under any regime. 


\subsection{Takeover premiums}

Malatesta and Walkling (1988) discuss in detail two competing hypotheses on the wealth effect of takeover defenses. The entrenchment hypothesis holds that takeover defenses reduce stockholder wealth by hindering takeovers. The previous analysis on pill use and takeover outcomes addresses this. The alternative stockholder interests hypothesis holds that takeover defenses allow target firms to secure a higher takeover premium. As a natural extension to our analysis, we therefore examine the determinants of the takeover premiums. This should provide further insights into the bargaining power of the target's management in negotiating with potential suitors. We are especially interested in testing whether the 1995 Delaware rulings directly or indirectly (via poison pills) increased takeover premiums.

Table 6 presents results from regressions of takeover premiums. Model a is based on the initial premiums offered, model b is based on premium increases, and models c and d are based on total premiums (i.e., the sum of the initial premiums and any premium increases).

The coefficient on multiple bidders is statistically insignificant in model a, but positive and statistically significant in models b-d. Thus, the presence of multiple bidders does not affect the initial bid price, but the ensuing bidding war between multiple bidders raises the premiums substantially. In fact, the magnitude of the coefficients suggests that a bidding war results in a total premium offered that is $18 \%$ higher, on average, than it is in single bidder takeover attempts. It is also consistent with the notion that low-ball initial takeover offers often end up attracting competing bidders.

The prior stock return of the target also affects the premium offered. The coefficient for prior stock return is negative and statistically significant across all models (the p-value varies from 0.016 in model a for the initial premium offered to less than 0.001 in models c and $\mathrm{d}$ for the 
total premium). Thus, it appears that firms are willing to offer more, both initially and in the form of subsequent price increases, when the target has recently experienced poor stock price performance.

In model a, the coefficients on the existing poison pill indicator variable is 0.042 with a p-value of 0.033 , suggesting that the initial bid premium is $4.2 \%$ higher when the target has a pill in place. In model b, the coefficient on the existing pill variable is 0.050 with a p-value of 0.011 , suggesting that these pills contribute another $5.0 \%$ to the premium via subsequent negotiations, for a total contribution to the premium of $4.2 \%+5.0 \%=9.2 \%$. In model b, we also include an indicator variable for morning-after poison pills that are adopted at some point after the targets have been put in play. The coefficient on this variable is 0.097 (p-value $<0.01$ ), suggesting that morning-after pills induce average premium increases of $9.7 \%$. In sum, the results from models a and b suggest that poison pills, irrespective of whether they were in place prior to the takeover attempt or adopted in response to the attempt, raised the total premium by a little less than $10 \%$. In model c, the coefficient on the poison pill indicator variable (which is the sum of the existing and morning-after poison pill indicator variables) is 0.105 with a p-value less than 0.01 , suggesting that poison pills raise total premiums by 10.5\%. All of our models suggest that poison pills benefit the target by extracting a higher premium from the bidder, consistent with Heron and Lie (2006).

Finally, we shift our attention to the effect of the 1995 Delaware rulings. For brevity, we focus on the effect on total premiums offered. In model c, the coefficient on the post 1995 dummy is -0.099 with a p-value of 0.015 , suggesting that the takeover premiums are lower during 1995-2011 than during 1985-1995. One might argue that the lower premiums since 1995 are attributable to a general effect from the 1995 Delaware rulings that extends beyond the state 
of Delaware. However, we would expect that if the 1995 Delaware rulings truly gave target firms more bargaining power, any acquirer would be forced to pay a higher premium. Thus, we interpret this result as inconsistent with the notion that the 1995 Delaware rulings increased the bargaining power of target firms. The coefficient on the interaction between the post 1995 dummy and the Delaware dummy is statistically insignificant, indicating no discernable effect of the 1995 Delaware rulings on takeover premiums among targets in Delaware relative to targets in other states. Lastly, we interact the poison pill dummy with the two variables for the 1995 Delaware rulings to gauge whether the rulings enhanced the effect of poison pills on takeover premiums. The coefficients on these interaction variables are also statistically insignificant. In sum, we find no evidence that the 1995 Delaware rulings allowed targets to extract a higher premium as a result of greater bargaining power, regardless of whether we search for a general effect or an indirect effect via the poison pills that the rulings address.

\section{Conclusion}

A large portion of the corporate governance literature seeks to determine how corporate governance and firm entrenchment affect corporate behavior. In that regard, multiple governance measures, e.g., the GIM and entrenchment indices, have been developed and applied. However, endogeneity concerns hamper inferences in studies that rely on these governance measures. Thus, researchers have searched for exogenous shocks that might resolve any endogeneity. The necessary conditions for such shocks are that they are exogenous, unexpected, and induce a material change in the governance/entrenchment for an identifiable set of firms. In this study, we focus on two case rulings on poison pills in Delaware in 1995 that have been used as an exogenous entrenchment shock. We believe that these rulings were exogenous to most firms. 
But it is not clear that they were unexpected in the prevailing legal environment. And we dispute that they materially entrenched firms.

To gauge the effect of the 1995 Delaware rulings, we undertake a comprehensive study of unsolicited takeover attempts spanning a decade before and more than a decade after the rulings. We find no evidence that the 1995 Delaware rulings had any entrenchment effect. In particular, Delaware firms are no less likely to be targeted after 1995. Furthermore, the rulings did not affect the use of poison pills among the targets, the effectiveness of the pills that were used, the completion rate of the takeover attempts, or the takeover premiums. Finally, we find no evidence for the common presumption that poison pills entrench firms and, therefore, that court cases validating pills, including those in Delaware in 1995, can be used as an entrenchment shock. That is, like Comment and Schwert (1995) and Heron and Lie (2006), we report that the use of pills enhances the takeover premium but does not reduce the takeover completion rate.

Our evidence casts serious doubt on both the use of the 1995 Delaware rulings as an exogenous shock and the inferences made by studies that examine the effect of these rulings on corporate behavior. Perhaps the documented effects of the rulings are merely coincidental or attributable to omitted factors, leading to the well-known publication bias in academic research (Sterling, Rosenbaum, and Weinkam, 1995). In any event, we caution against relying on the 1995 Delaware rulings to infer the effect of entrenchment and encourage corporate governance researchers to identify alternative shocks or methodologies to mitigate endogeneity concerns. 


\section{REFERENCES}

Atanasov, Vladimir, and Bernard Black. 2015a. Shock-based causal inference in corporate finance research. Critical Finance Review, forthcoming.

Atanasov, Vladimir, and Bernard Black. 2015b. The trouble with instruments: ReExamining shock-based IV designs. Working paper.

Bereskin, Frederick L., and David C. Cicero. 2013. CEO compensation contagion: Evidence from an exogenous shock. Journal of Financial Economics 107, 477-493.

Cain, Matthew D., Steven M. Davidoff, and Stephen B. McKeon. 2014. Do takeover laws matter? Evidence from 45 years of hostile takeovers. Working paper.

Clark Boardman Co., Inc. 1988-1998. Corporate antitakeover defenses: The poison pill device. 11 vols. New York. NY.

Comment, Robert, and G. William Schwert. 1995. Poison or placebo? Evidence on the deterrence and wealth effects of modern antitakeover measures. Journal of Financial Economics 39, 3-43.

Cremers, Martijn, and Allen Ferrell. 2014. Thirty years of shareholder rights and firm value, Journal of Finance 69, 1167-1196.

Daines, Robert. 2001. Does Delaware law improve firm value? Journal of Financial Economics 62, 525-558.

Heron, Randall A., and Erik Lie. 2006. On the use of poison pills and defensive payouts by takeover targets. Journal of Business 79, 271-295.

Kaplan, Steven N. and Bernadette A. Minton. 2012. How has CEO turnover changed? International Review of Finance 12:1, 57-87.

Low, Angie. 2009. Managerial risk-taking behavior and equity-based compensation. Journal of Financial Economics 92, 470-490.

Malatesta, Paul H. and Ralph A. Walkling. 1988. The impact of 'poison pill' securities on stockholder wealth. Journal of Financial Economics 20, 347-370.

Rauh, Joshua D. 2006. Own company stock in defined contribution pension plans: A takeover defense? Journal of Financial Economics 81, 379-410.

Ryngaert, Michael D. 1988. The effect of poison pill securities on shareholder wealth. Journal of Financial Economics 20, 377-417. 
Ryngaert, Michael D. 1989. Firm valuation, takeover defenses, and the Delaware Supreme Court. Financial Management 18, 20-28.

Ryngaert, Michael D, and Ralph Scholten. 2010. Have changing takeover defense rules and strategies entrenched management and damaged shareholders? The case of defeated takeover bids. Journal of Corporate Finance 16, 16-37.

Sterling, T. D., W. L. Rosenbaum, and J. J. Weinkam. 1995. Publication decisions revisited: The effect of the outcome of statistical tests on the decision to publish and vice versa. The American Statistician 49, 108-112.

Subramanian, Guhan. 2004. The disappearing Delaware effect. The Journal of Law, Economics, and Organization 20, 32-59.

Yun, Hayong. 2009. The choice of corporate liquidity and corporate governance. The Review of Financial Studies 22, 1447-1475. 
Table 1

Descriptive statistics

This table presents descriptive statistics for the targets of 662 unsolicited takeover attempts from 1985 to 2009 . Figures derived from financial statements are for the fiscal year preceding the announcement of the takeover attempt, unless otherwise indicated. Equity market values are as of 20 days prior to the announcement of the takeover attempt. Insider ownership, CEO compensation, and the Board of Directors data come from the most recent proxy statement prior to the announced takeover attempt. CEO compensation is the sum of the CEO's salary plus cash bonus for the year prior to the takeover announcement. Industry adjusted OIBD is the paired difference between operating income / assets for the sample firm and the median figure for firms in the same Fama-French 48 industry classification. Stock return for prior year is the cumulative stock return over the year ending 20 days prior to the announcement date of the takeover attempt. Market return for prior year is the compounded value-weighted CRSP market return over the year ending 20 days prior to the announcement date of the takeover attempt. Industry return for prior year is the compounded value-weighted return for firms in the same Fama-French 48 Industry classification over the year ending 20 days prior to the announcement date of the takeover attempt. Initial premium offered is the initial offer price divided by the price 20 days prior, less one. Premium increase is the percentage increase in the bid price, relative to the price 20 days prior to the initial offer. Completed offers are those that were completed by the unsolicited bidder.

\begin{tabular}{lcc}
\hline & Mean & Median \\
\hline & & \\
Market value of equity (\$ millions) & 1,112 & 191 \\
Total liabilities / Assets & 0.561 & 0.565 \\
Cash and short-term investments / Assets & 0.113 & 0.058 \\
Market-to-book assets & 1.36 & 1.14 \\
Insider ownership & 0.133 & 0.083 \\
CEO compensation (\$ thousands) & 669 & 444 \\
Fraction of outside directors & 0.588 & 0.615 \\
Industry-adjusted OIBD & 0.026 & 0.016 \\
Stock return for prior year & 0.052 & 0.019 \\
Market return for prior year & 0.125 & 0.161 \\
Industry return for prior year & 0.243 & 0.222 \\
Initial premium offered & 0.364 & 0.333 \\
Premium increase & 0.147 & 0.081 \\
& & \\
\hline & Number & Fraction (\%) \\
\hline & & \\
Targets with existing poison pills & 286 & 43.2 \\
Targets that adopted morning-after pills & 83 & 12.5 \\
Staggered board & 339 & 51.2 \\
CEO=Chairperson of board & 411 & 62.1 \\
Pill and Staggered board & 204 & 30.8 \\
Contests with multiple bidders & 266 & 40.2 \\
Completed offers & 138 & 20.9 \\
Acquired by a competing bidder & 187 & 28.3 \\
Delaware incorporation & 393 & 59.4 \\
\hline
\end{tabular}


Table 2

Univariate comparisons

This tables presents descriptive statistics for subsamples based on whether the targeted firms were ultimately acquired and whether the targeted firms employed a poison pill. Financial statement figures are for the fiscal year preceding the announcement of the takeover attempt, unless otherwise indicated. Equity market values are as of 20 days prior to the announcement of the takeover attempt, or the first announcement in a multiple bidder contest. Insider ownership, CEO compensation, and the Board of Director information come from the proxy statement prior to the announced takeover attempt. CEO compensation is the sum of salary plus cash bonus for the year prior to the takeover announcement. Industry adjusted OIBD is the paired difference between operating income / assets for the sample firm and the median figure for firms in the same Fama-French 48 industry classification. Stock return for prior year is the cumulative stock return over the year ending 20 days prior to the announcement date of the takeover attempt. Initial premium offered is relative to the price 20 days prior to the initial offer. Premium increase is the percentage increase in the bid price, scaled by the price 20 days prior to the initial offer. Total premium is the sum of the initial premium and premium increase. In the case of multiple bidders, initial premium offered is based on the initial bid and total premium is based on the final offer, whether successful or not (both scaled by the stock price 20 days prior to the initial offer). * and ** denote that the difference between the subsamples is statistically significant at the $5 \%$ and $1 \%$ levels, respectively.

\begin{tabular}{|c|c|c|c|c|c|c|c|c|}
\hline & \multicolumn{4}{|c|}{ Sample partitioned on outcome } & \multicolumn{4}{|c|}{ Sample partitioned on poison pills } \\
\hline & \multicolumn{2}{|c|}{$\begin{array}{l}\text { Acquired } \\
(n=325)\end{array}$} & \multicolumn{2}{|c|}{$\begin{array}{c}\text { Unsuccessful offers } \\
(\mathrm{n}=337)\end{array}$} & \multicolumn{2}{|c|}{$\begin{array}{l}\text { Firms with poison pills } \\
(\mathrm{n}=369)\end{array}$} & \multicolumn{2}{|c|}{$\begin{array}{c}\text { Firms w/o poison pills } \\
(\mathrm{n}=293)\end{array}$} \\
\hline & Mean & Median & Mean & Median & Mean & Median & Mean & Median \\
\hline Market value of equity (\$ millions) & 1,225 & 227 & 1,003 & 157 & $1,419 *$ & $272 * *$ & 726 & 104 \\
\hline Total liabilities / Assets & 0.565 & 0.565 & 0.557 & 0.564 & 0.557 & 0.563 & 0.566 & 0.567 \\
\hline Cash / Assets & $0.101^{*}$ & 0.054 & 0.125 & 0.064 & 0.115 & 0.057 & 0.112 & 0.060 \\
\hline Market-to-book assets & 1.36 & 1.16 & 1.36 & 1.13 & 1.40 & $1.20 * *$ & 1.31 & 1.09 \\
\hline Insider ownership & 0.124 & $0.070 *$ & 0.142 & 0.097 & $0.090 * *$ & $0.060 * *$ & 0.188 & 0.122 \\
\hline CEO compensation ( $\$$ thousands) & 685 & 464 & 654 & 418 & $740 *$ & $525 * *$ & 580 & 355 \\
\hline Fraction of outside directors & 0.594 & 0.615 & 0.581 & 0.615 & $0.618 * *$ & $0.667 * *$ & 0.550 & 0.571 \\
\hline Industry-adjusted OIBD & 0.032 & 0.018 & 0.021 & 0.011 & $0.037 * *$ & $0.022 * *$ & 0.013 & 0.007 \\
\hline Stock return for prior year & 0.061 & 0.040 & 0.043 & -0.007 & 0.032 & 0.000 & 0.077 & 0.042 \\
\hline Initial premium offered (\%) & $0.382 *$ & $0.357 *$ & 0.347 & 0.309 & 0.379 & $0.361^{* *}$ & 0.345 & 0.313 \\
\hline Premium increase (\%) & $0.241 * *$ & $0.197 * *$ & 0.056 & 0.000 & $0.177 * *$ & $0.111^{* *}$ & 0.109 & 0.000 \\
\hline Total premium (\%) & $0.623 * *$ & $0.556 * *$ & 0.409 & 0.349 & $0.557 * *$ & $0.490 * *$ & 0.454 & 0.431 \\
\hline Existing poison pill & 0.449 & & 0.415 & & 0.775 & & & \\
\hline Morning-after pill & 0.142 & & 0.110 & & 0.225 & & & \\
\hline Staggered board & 0.517 & & 0.507 & & $0.553^{*}$ & & 0.461 & \\
\hline $\mathrm{CEO}=$ Chairperson of board & 0.631 & & 0.611 & & 0.650 & & 0.584 & \\
\hline Delaware incorporation & 0.575 & & 0.611 & & $0.634^{*}$ & & 0.543 & \\
\hline
\end{tabular}


Table 3

\section{Unsolicited takeover attempts across time}

This table presents descriptive statistics based on whether the offers were made before December 31, 1995 and whether the firms were incorporated in Delaware. Panels A and B present statistics for firms incorporated in Delaware and other states, respectively. Poison Pill is an indicator variables equal to one if the targeted firm had a poison pill defense, either in place prior to the takeover contest or adopted as a morning-after pill after the takeover contest began. Staggered Board is an indicator variable equal to one if the target had a staggered board. * and ** denote statistically significant differences between the time periods within the same panel at the $5 \%$ and $1 \%$ levels, respectively. ${ }^{\dagger}$ and ${ }^{\dagger+}$ denote statistically significant differences across the panels within the same time period at the $5 \%$ and $1 \%$ levels, respectively.

1985-1995 1996-2009

Panel A: Delaware incorporation

Number of observations

Acquired by unsolicited bidder

Acquired by bidder or a competing bidder

Premium offered (mean)

Premium offered (median)

Poison Pill

Staggered Board

Panel B: Non-Delaware incorporation

Number of observations

Multiple bidders

Acquired by unsolicited bidder

Acquired by bidder or a competing bidder

Premium offered (mean)

Premium offered (median)

Poison Pill

Staggered Board
226

0.367

0.226

167

0.425

0.168

0.491

0.455

$0.537 *$

$0.455 *$

0.460

0.408

$0.589+$

0.605

0.549

0.533

167

102

0.437

0.382

0.246

0.177

0.563

0.431

$0.561 * *$

0.456

$0.508 * *$

0.437

0.485

0.529

0.461

0.480 
Table 4

Probability that a poison pill plan is adopted

This table presents logistic regressions of the probability of the target adopting a poison pill plan. The dependent variable equals one if the targeted firm had a poison pill defense, either in place prior to the takeover contest or adopted as a morningafter pill after the takeover contest began. Figures derived from financial statements are for the fiscal year preceding the announcement of the takeover attempt, unless otherwise indicated. Equity market values are as of 20 days prior to the announcement of the takeover attempt. Insider ownership figures represent the fractional ownership of officers and directors (taken from proxy statements). Staggered board is an indicator variable equal to one if the target had a staggered board. CEO compensation is the sum of the CEO's salary plus cash bonus for the year prior to the takeover announcement. $\mathrm{CEO}=$ Chairperson is an indicator variable equal to one if the target's CEO was also the chairperson of the Board. Industry adjusted OIBD is the paired difference between operating income / assets for the sample firm and the median figure for firms within the same Fama-French 48 industry classification. Stock return for prior year is the cumulative stock return over the year ending 20 days prior to the announcement date of the takeover attempt. Industry-adjusted stock return is the difference between the firm's stock return and the compounded value-weighted return for firms in the same Fama-French 48 Industry classification over the year ending 20 days prior to the announcement date of the takeover attempt. The likelihood ratio index is defined as [1-(log likelihood at convergence)/(log likelihood at zero)], and is similar to the $\mathrm{R}^{2}$ statistic for a linear regression.

\begin{tabular}{lrl}
\hline & Coeff. & p-value \\
\hline Intercept & -2.621 & 0.049 \\
Log of equity market value & 0.122 & 0.113 \\
Total liabilities / Assets & -0.689 & 0.109 \\
Market-to-book assets & 0.097 & 0.446 \\
Insider ownership & -4.889 & 0.000 \\
Staggered board & 0.336 & 0.056 \\
Log of CEO compensation & 0.115 & 0.336 \\
Fraction of outside directors & 0.559 & 0.237 \\
CEO = Chairperson of board & 0.072 & 0.693 \\
Industry adjusted OIBD & 2.345 & 0.028 \\
Stock return for prior year & -0.636 & 0.081 \\
Industry-adjusted stock return & 0.565 & 0.121 \\
Delaware & 0.467 & 0.038 \\
Post 1995 & 0.133 & 0.640 \\
Delaware * Post 1995 & -0.194 & 0.593 \\
& & \\
N & & 662 \\
Likelihood ratio statistic & & 119.38 \\
Likelihood ratio index & & $13.13 \%$ \\
\hline
\end{tabular}


Table 5

Probability that the takeover offer succeeds or the target is acquired by any bidder

This table presents logistic regressions of the probability that the unsolicited takeover offer succeeds (model a) or the probability that the targeted firm is taken over by any of the bidders (model b). The dependent variable equals one if the unsolicited bidder's takeover attempt succeeded. Figures derived from financial statements are for the fiscal year preceding the announcement of the takeover attempt, unless otherwise indicated. Equity market values are as of 20 days prior to the announcement of the takeover attempt. Multiple bidders is an indicator variable that equals one if there are competing bidders. Poison pill is an indicator variable equal to one if the target had a poison pill prior to when the outcome of the takeover attempt was determined. Insider ownership figures represent the fractional ownership of officers and directors (taken from proxy statements). Staggered board is an indicator variable equal to one if the target had a staggered board. CEO compensation is the sum of the CEO's salary plus cash bonus for the year prior to the takeover announcement. $\mathrm{CEO}=$ Chairperson is an indicator variable equal to one if the target's CEO was also the chairperson of the Board. Industry adjusted OIBD is the paired difference between operating income / assets for the sample firm and the median figure for firms within the same Fama-French 48 industry classification. Stock return for prior year is the cumulative stock return over the year ending 20 days prior to the announcement date of the takeover attempt. Industry-adjusted stock return is the difference between the firm's stock return and the compounded value-weighted return for firms in the same Fama-French 48 Industry classification over the year ending 20 days prior to the announcement date of the takeover attempt. Initial premium offered is the initial offer price divided by the price 20 days prior, less one. Total premium is defined in Table 2. The likelihood ratio index is defined as [1-(log likelihood at convergence)/(log likelihood at zero)], and is similar to the $\mathrm{R}^{2}$ statistic for a linear regression.

\begin{tabular}{lrlrl}
\hline & \multicolumn{2}{c}{$\begin{array}{c}\text { Offer succeeds } \\
\text { (a) }\end{array}$} & \multicolumn{2}{c}{ Target is acquired } \\
& (b) \\
\hline & Coeff. & p-value & Coeff. & p-value \\
\hline Intercept & -3.028 & 0.049 & -3.465 & 0.017 \\
Log of equity market value & 0.178 & 0.043 & -0.014 & 0.874 \\
Total liabilities / Assets & -0.653 & 0.218 & -0.725 & 0.159 \\
Market-to-book assets & 0.131 & 0.257 & 0.127 & 0.298 \\
Multiple bidders & -0.948 & 0.000 & 2.879 & 0.000 \\
Poison pill & -0.114 & 0.766 & 0.473 & 0.259 \\
Insider ownership & -0.606 & 0.529 & -0.397 & 0.652 \\
Staggered board & 0.109 & 0.603 & -0.096 & 0.651 \\
Log of CEO compensation & -0.065 & 0.631 & 0.111 & 0.367 \\
Fraction of outside directors & 0.568 & 0.331 & 0.611 & 0.287 \\
CEO = Chairperson of board & 0.259 & 0.245 & 0.199 & 0.374 \\
Industry adjusted OIBD & 1.046 & 0.346 & 1.570 & 0.172 \\
Stock return for prior year & 0.493 & 0.223 & 0.189 & 0.666 \\
Industry-adjusted stock return & -0.490 & 0.415 & 0.045 & 0.920 \\
Delaware & -0.407 & 0.312 & 0.230 & 0.570 \\
Post 1995 & -0.309 & 0.523 & -0.288 & 0.553 \\
Delaware * Post 1995 & -0.073 & 0.916 & -0.515 & 0.433 \\
Poison Pill * Delaware & 0.371 & 0.475 & -0.606 & 0.268 \\
Poison Pill * Post 1995 & -0.349 & 0.599 & -0.582 & 0.382 \\
Poison Pill * Del. * Post 1995 & 0.228 & 0.797 & 0.942 & 0.280 \\
Initial premium offered (\%) & 0.711 & 0.114 & 1.386 & 0.004 \\
Premium increase (\%) & 1.641 & 0.000 & 3.586 & 0.000 \\
& & & & \\
N & & 662 & & 662 \\
Likelihood Ratio Statistic & & 54.96 & & 328.29 \\
Likelihood Ratio Index & & $8.11 \%$ & & $35.78 \%$ \\
\hline
\end{tabular}




\section{Table 6 \\ Regressions of takeover premiums}

This table presents regressions of the takeover premiums. The dependent variable in model a is the initial premium scaled by the target's price 20 days prior to the initial offer. The dependent variable in model $\mathrm{b}$ is the premium increase in percentage. The dependent variable in models $\mathrm{c}$ and $\mathrm{d}$ is the total percentage premium (initial premium plus any premium increase) offered (relative to the target's price 20 days prior to the initial offer). In the case of multiple bidders, the initial premium offered is based on the initial bid and premium increase and total premium are based on the final offer, whether successful or not (both scaled by the stock price 20 days prior to the initial offer). Figures derived from financial statements are for the fiscal year preceding the announcement of the takeover attempt, unless otherwise indicated. Equity market values are as of 20 days prior to the announcement of the takeover attempt. Multiple bidders is an indicator variable that equals one if there are competing bidders. Existing poison pill is an indicator variable equal to one if the target had a poison pill prior to when the takeover attempt was announced. Morning-after pill is an indicator variable that equals one if the targeted firm adopted a poison pill after the takeover attempt was announced, but before the outcome was determined. Poison pill is an indicator variable equal to one if the target had a poison pill prior to when the outcome of the takeover attempt was determined. Insider ownership figures represent the fractional ownership of officers and directors (taken from proxy statements). Staggered board is an indicator variable equal to one if the target had a staggered board. CEO compensation is the sum of the CEO's salary plus cash bonus for the year prior to the takeover announcement. $\mathrm{CEO}=$ Chairperson is an indicator variable equal to one if the target's CEO was also the chairperson of the Board. Industry adjusted OIBD is the paired difference between operating income / assets for the sample firm and the median figure for firms within the same Fama-French 48 industry classification. Stock return for prior year is the cumulative stock return over the year ending 20 days prior to the announcement date of the takeover attempt. Industry-adjusted stock return is the difference between the firm's stock return and the compounded value-weighted return for firms in the same Fama-French 48 Industry classification over the year ending 20 days prior to the announcement date of the takeover attempt.

\begin{tabular}{|c|c|c|c|c|c|c|c|c|}
\hline & \multirow{2}{*}{\multicolumn{2}{|c|}{$\begin{array}{l}\text { Initial prem. } \\
\text { (a) }\end{array}$}} & \multirow{2}{*}{\multicolumn{2}{|c|}{$\begin{array}{l}\text { Prem. increase } \\
\text { (b) }\end{array}$}} & \multicolumn{4}{|c|}{ Total premium } \\
\hline & & & & & ( & & $(c$ & \\
\hline & Coeff. & p-val. & Coeff. & p-val. & Coeff. & p-val. & Coeff. & p-val. \\
\hline Intercept & 0.330 & 0.015 & -0.188 & 0.136 & 0.146 & 0.427 & 0.125 & 0.499 \\
\hline Log of equity market value & -0.014 & 0.073 & -0.002 & 0.738 & -0.017 & 0.116 & -0.017 & 0.120 \\
\hline Total liabilities / Assets & 0.064 & 0.140 & 0.016 & 0.702 & 0.082 & 0.172 & 0.078 & 0.196 \\
\hline Market-to-book assets & 0.012 & 0.311 & 0.001 & 0.925 & 0.013 & 0.432 & 0.012 & 0.446 \\
\hline Multiple bidders & 0.000 & 0.987 & 0.178 & 0.000 & 0.179 & 0.000 & 0.179 & 0.000 \\
\hline Existing poison pill & 0.042 & 0.033 & 0.050 & 0.010 & & & & \\
\hline Morning-after pill & & & 0.097 & 0.000 & & & & \\
\hline Poison pill & & & & & 0.105 & 0.000 & 0.133 & 0.007 \\
\hline Insider ownership & -0.008 & 0.912 & -0.018 & 0.799 & -0.015 & 0.887 & -0.027 & 0.797 \\
\hline Staggered board & -0.022 & 0.233 & 0.016 & 0.348 & -0.007 & 0.789 & -0.009 & 0.721 \\
\hline Log of CEO compensation & 0.012 & 0.330 & 0.022 & 0.051 & 0.033 & 0.044 & 0.034 & 0.039 \\
\hline Fraction of outside directors & 0.027 & 0.587 & 0.020 & 0.659 & 0.045 & 0.500 & 0.042 & 0.535 \\
\hline CEO = Chairperson of board & 0.005 & 0.804 & 0.011 & 0.520 & 0.016 & 0.534 & 0.017 & 0.529 \\
\hline Industry adjusted OIBD & -0.142 & 0.152 & -0.072 & 0.434 & -0.219 & 0.108 & -0.229 & 0.094 \\
\hline Stock return for prior year & -0.090 & 0.015 & -0.109 & 0.002 & -0.198 & 0.000 & -0.197 & 0.000 \\
\hline Industry-adj. stock return & -0.024 & 0.536 & 0.074 & 0.037 & 0.049 & 0.351 & 0.047 & 0.367 \\
\hline Delaware & 0.019 & 0.425 & -0.035 & 0.108 & -0.018 & 0.587 & -0.010 & 0.838 \\
\hline Post 1995 & -0.027 & 0.362 & -0.071 & 0.011 & -0.099 & 0.015 & -0.034 & 0.556 \\
\hline Delaware * Post 1995 & -0.068 & 0.072 & 0.039 & 0.269 & -0.029 & 0.582 & -0.097 & 0.206 \\
\hline Poison Pill * Delaware & & & & & & & -0.018 & 0.777 \\
\hline Poison Pill * Post 1995 & & & & & & & -0.125 & 0.119 \\
\hline Poison Pill * Del. * Post 1995 & & & & & & & 0.131 & 0.204 \\
\hline $\mathrm{N}$ & & 662 & & 662 & & 662 & & 662 \\
\hline F-Statistic for Regression & & 3.46 & & 9.24 & & 7.68 & & 6.61 \\
\hline Adjusted $\mathrm{R}^{2}$ & & 0.056 & & 0.175 & & 0.139 & & 0.139 \\
\hline
\end{tabular}

